Rok XIV (2019) | 2 (28) | s. 197-207

https://doi.org/10.12797/LV.14.2019.28.13

Mariola Jakubowicz (1)

Instytut Slawistyki Polskiej Akademii Nauk, Warszawa

mjakub7@interia.pl

\title{
RUMUŃSKA REDAKCJA JĘZYKA CERKIEWNOSŁOWIAŃSKIEGO - ZARYS PROBLEMATYKI
}

Słowa klucze: język cerkiewnosłowiański, redakcja rumuńska, adaptacja graficzna

Keywords: Church Slavonic, Romanian redaction, graphic adaptation

Artykuł ma na celu przybliżenie czytelnikom mało znanej redakcji języka cerkiewnosłowiańskiego. Jej powstanie w kraju niesłowiańskim może budzić zdziwienie, jeśli nie weźmie się pod uwagę faktu, że ludność mieszkająca na terenie dzisiejszej Rumunii wyznawała (i do dziś w większości wyznaje) prawosławie, podobnie jak Słowianie zamieszkujący kraje graniczące z Rumunią od północy i południa. Ze względu na dominującą rolę Kościoła w średniowieczu język religii stawał się w sposób naturalny językiem administracji i kultury. Rozpowszechnienie języka cerkiewnosłowiańskiego na terenach zróżnicowanych językowo doprowadziło do absorbowania elementów języków używanych przez poszczególne nacje i do powstawania różnych odmian języka cerkiewnosłowiańskiego zwanych redakcjami. Liczba redakcji języka cerkiewnosłowiańskiego jest przez badaczy różnie określana. W każdym podziale wymienia się jednak redakcje: ruską, ukraińską, bułgarską, serbską i chorwacką. Istnienie redakcji rumuńskiej jest uznawane przez takich slawistów, jak np. Josip Hamm (1958: 189), który uważa ją za szóstą redakcję, lub Stefan Mladenov (1979: 81), który określa ją jako redakcję języka średniobułgarskiego, podkreślając przy tym znaczenie redakcji rumuńskiej dla śledzenia rozwoju samego języka bułgarskiego. Spośród polskich slawistów uwzględnia ją Leszek Moszyński (2006: 370). 
Można się zastanawiać nad poprawnością samego określenia redakcja rumuń$s k a^{1}$, jako że w czasach, gdy na ziemie dzisiejszej Rumunii dotarł język cerkiewnosłowiański, etnos mówiący językiem rumuńskim (wołoskim)² nie tworzył jednego organizmu państwowego, ale wiele małych państewek, w XIV w. zjednoczonych w dwa: Mołdawię i Wołoszczyznę. Również w Siedmiogrodzie język cerkiewnosłowiański pełnił funkcję języka kultury, na co wskazują liczne teksty z tych terenów pisane w nim właśnie. Ze względu na bardzo złożoną sytuację etniczną Siedmiogrodu był tam używany w piśmie zarówno język łaciński, jak i węgierski oraz niemiecki. O wyborze języka nie tylko liturgii, ale również piśmiennictwa decydowało kryterium wyznaniowe.

Uznanie języka słowiańskiego za język liturgii wiązało się z przyjęciem chrześcijaństwa z terenów Bułgarii. Legenda przekazana przez Paisija Chilendarskiego mówi, że car Asen I (panujący w latach 1188-1196) nakazał Wołochom, którzy do jego czasów wyznawali obrządek rzymski i czytali po łacinie, ponieważ łączyło ich z łacinnikami pochodzenie i język, przyjąć wiarę prawosławną i czytać po bułgarsku, grożąc przy tym obcięciem języka tym, którzy czytaliby po łacinie (Ivanov 1914: 36-37). W ten sposób cerkiewnosłowiański miał wejść na ziemie wołoskie. W tej legendzie zapewne prawdziwe jest to, że język cerkiewnosłowiański został przyjęty w początkach drugiego państwa bułgarskiego, zwanego państwem Bułgarów i Wołochów. Wcześniejsze kontakty ludności wołoskiej z językiem cerkiewnosłowiańskim (a może nawet staro-cerkiewno-słowiańskim) są rozważane przez badaczy rumuńskich w związku z informacjami z żywota Nauma Ochrydzkiego o przeniesieniu się po śmierci Metodego niektórych jego uczniów na tereny Dacji i Dalmacji. Zagadnienie to zostało poruszone w artykule Gheorghego Mihăilă (1973: 6) dotyczącym rumuńskiej redakcji cerkiewnosłowiańskiej.

Za datę usamodzielnienia się organizacji kościelnej na Wołoszczyźnie można uznać rok 1359, kiedy to w Curtea de Argeş została ustanowiona metropolia prawosławna. Jednak daty konkretnych aktów nie mówią wiele o czasie rzeczywistych wpływów chrześcijańskich, idących od strony Bizancjum, które wiążą się z wspólnym państwem Bułgarów i Wołochów, czyli drugim państwem bułgarskim. Warto w tym miejscu zacytować opinię Tomasza Klimkowskiego:

Z uwagi na szczupłość danych historycznych czas i miejsce procesu rechrystianizacji Wołochów można ustalić jedynie w przybliżeniu. Obrońcy teorii o północnodunajskim pochodzeniu Rumunów wskazują na fakt, że w IX-X w. dawna prowincja Dacja

1 Odpowiadający jej termin slavo-romîn został wprowadzony do literatury naukowej przez Ioana Bogdana w roku 1889; wcześniej literatura napisana w tym języku była określana jako valaho-bulgară (влахобългарска).

2 Termin wołoski w polskiej tradycji literackiej występuje w innym znaczeniu niż określenie wczesnej fazy języka rumuńskiego stosowane przez językoznawców. W niniejszym artykule termin wołoski jest używany w znaczeniu językoznawczym, wymiennie z terminem rumuński. 
pozostawała pod panowaniem Bułgarów, których władca Borys nawrócił się w $866 \mathrm{r}$. na chrześcijaństwo, i wtedy też obrządek bizantyńsko-słowiański musiał zostać zaszczepiony wśród Wołochów z Dacji. Wydaje się jednak, że był to czas zbyt krótki na przeprowadzenie dość jednak zaawansowanej chrystianizacji. Zwolenników tezy o południowodunajskim pochodzeniu wszystkich Wołochów i późniejszej migracji części z nich na tereny obecnej Rumunii nie krępują tak ścisłe ramy chronologiczne. Zgodnie z tą teorią należałoby uznać, że Wołosi przyjęli obrządek wschodni między IX w. (chrzest Borysa i początek chrystianizacji Bułgarów) a XII-XIII w. (najpóźniejsza datacja migracji przyszłych mieszkańców Rumunii na północ od Dunaju), z rąk Bułgarów (względnie Serbów) (Klimkowski 2011: 53).

Historycy rumuńscy podkreślają, że początki chrześcijaństwa rumuńskiego są starsze i niewątpliwie łączą się z kulturą zachodnią, na co wskazuje pochodzenie podstawowej terminologii chrześcijańskiej, np.: Dumnezeu 'Bóg', înger 'anioł', biserică 'kościól', cruce 'krzyż’3 ${ }^{3}$ Na tej podstawie datują je na III/IV w. Nie można tu mówić o konkretnym akcie chrztu, ale o sukcesywnych wpływach, prawdopodobnie idących z Mezji. Ta wczesna chrystianizacja musiała być jednak powierzchowna, skoro było możliwe zastąpienie jej obrządkiem greckim. Z drugiej strony znaczna część terminów dotyczących obrzędowości chrześcijańskiej i organizacji kościelnej jest pochodzenia greckiego (bizantyjskiego) albo słowiańskiego. Z języka cerkiewnosłowiańskiego pochodzi nawet nazwa Ducha Świętego Duhul sfint (więcej na ten temat: ibid.: 50-53).

Najstarsze teksty w języku słowiańskim z terenów Rumunii pochodzą z XIII w., a największe ich rozpowszechnienie przypada na okres od XIV do XVI w. Wprawdzie językoznawcy rumuńscy często wymieniają w tym kontekście inskrypcje słowiańskie pochodzące z terenu Dobrudży, w tym najstarszą, datowaną na $943 \mathrm{r}$. (Mihăilă 1972: 78-103; Djamo-Diaconiță 1971: 7), jednak wobec faktu, że Dobrudża należała wtedy do Bułgarii oraz że nie ma jednoznacznych dowodów na zamieszkiwanie jej w tym czasie przez przodków dzisiejszych Rumunów, nie ma też powodu, aby włączać te inskrypcje do korpusu zabytków redakcji rumuńskiej.

W czasach powstania i rozwoju omawianej redakcji języka cerkiewnosłowiańskiego państwo rumuńskie jako całość jeszcze nie istniało, trudno więc mówić o jednolitej postaci języka rumuńskiego na terenach dzisiejszej Rumunii, a tym bardziej o jednolitej postaci używanego tam języka cerkiewnosłowiańskiego. Teksty powstające na terenie Siedmiogrodu (a począwszy od lat 30. XV w. także na terenie Wołoszczyzny) charakteryzowały się znacznym wpływem serbskim. Na terenie Mołdawii widoczne były natomiast wpływy redakcji ruskiej, np. w wokalizacji jerów. W Maramureszu i w północnej części Siedmiogrodu obecne były wpływy

3 Terminologię pochodzenia łacińskiego we współczesnym języku rumuńskim reprezentuje ponad dwadzieścia wyrazów, których listę zamieszcza w swym artykule Tomasz Klimkowski (2011: $45-46)$. 
redakcji ruskiej o wyraźnym zabarwieniu ukraińskim (zakarpackim). Tym, co decyduje o wyróżnianiu jednej redakcji rumuńskiej (nie zaś wołoskiej, mołdawskiej i siedmiogrodzkiej), jest z jednej strony jej wspólne pochodzenie jako odgałęzienia redakcji średniobułgarskiej, z drugiej - obecny na całym terenie wpływ żywego języka rumuńskiego (wołoskiego).

Charakter tekstów zmieniał się z upływem czasu. Pierwsze zabytki z XIII/XIV w. dokładniej niż późniejsze zachowywały w fonetyce i morfologii tradycyjne cechy języka staro-cerkiewno-słowiańskiego: pełną deklinację, samogłoski nosowe i jat’, prawidłową dystrybucję jerów twardych i miękkich. W XV w. pojawiły się oddziaływania innych redakcji, pozostających pod wpływem języków narodowych charakterystycznych dla sąsiadujących krajów słowiańskich.

Na zapis samogłosek w redakcji rumuńskiej wpływ mogły mieć różne czynniki, z których najważniejszym było pochodzenie pisarzy. Wydaje się logiczne, że najwcześniejsze zapisy były sporządzane przez pisarzy słowiańskich, a w miarę umacniania się cerkiewnosłowiańskiego jako języka administracji teksty coraz częściej tworzone były przez pisarzy pochodzenia wołoskiego. Nie jest jednak możliwe dokładne ustalenie narodowości pisarzy. Po pierwsze, tylko w 34\% przypadków zapisy są sygnowane $e^{4}$. Po drugie, imię pisarza nie zawsze świadczy o jego pochodzeniu, a często wprowadza w błąd. Badaczka tekstów rumuńsko-słowiańskich pochodzących z Muntenii Lucia Djamo-Diaconiță (1971: 17-18) przytacza przykłady zestawień słowiańskich imion pisarzy $\mathrm{z}$ ich zapisami, wskazującymi na rumuńską podstawę językową ich autorów (np. D. i C. l. poj. r.ż. na -ei, jak w deklinacji rumuńskiej: dèvei Marii; Onei NO). W miarę rozpowszechniania się znajomości cerkiewnosłowiańskiego wśród ludności wołoskiej narastały też wpływy jej podstawy językowej na kształt tekstów. Wspomniana L. Djamo-Diaconiță podkreśla, że, w zestawieniu z zapisami z ościennych krajów słowiańskich, zapisy wołoskie cechują się zdecydowanie większą niekonsekwencją. Jeden znak może oddawać różne głoski i odwrotnie: jedna głoska bywa zapisywana na kilka sposobów. Nie dziwi to zresztą, jeśli przyjmie się ogólnie uznawany pogląd, że pisarze posługiwali się językiem sztucznym, odrębnym od ich własnego. Zresztą w ogóle umiejętność pisania w tym czasie dopiero się kształtowała. Używanie grafemów cyrylickich przez ludność z inną niż słowiańska bazą artykulacyjną w zakresie samogłosek ${ }^{5}$ natrafiało na spore trudności.

Do poważniejszych problemów z oddaniem samogłosek dochodziło zwłaszcza w tych wypadkach, gdy zamieszanie zaistniało już w podstawie, którą była redakcja bułgarska. Do zmieszania przednich i tylnych samogłosek nosowych dochodziło zarówno w rdzeniach wyrazu (np. da sęt zamiast sot(z) 'aby byli'), jak i w końcówkach, np. w 1 os. l. poj. i 3. os. l. mn. (np. molę w miejsce molo 'proszę, modlę się’). Obecność

\footnotetext{
4 Dane procentowe dotyczą Muntenii (Djamo-Diaconiță 1971: 17).

5 Jak wyjaśniam w dalszej części artykułu, konsonantyczna baza artykulacyjna języka rumuńskiego jest bliska słowiańskiej.
} 
graficznych znaków samogłosek nosowych wskazuje na znaczną siłę tradycji; należy wziąć pod uwagę fakt, że pisarze redakcji rumuńskiej mieli do czynienia już wyłącznie z samogłoskami denazalizowanymi. Tradycyjny zapis samogłosek nosowych utrzymywał się jeszcze w XV w., przy czym w drugiej połowie tego stulecia liczba takich zapisów wyraźnie spadła, utrzymując się przede wszystkim w tradycyjnych formułach adresatywnych (ibid.: 35 ). Powszechnym zjawiskiem było także mieszanie w zapisach samogłoski nosowej tylnej $\varrho$ z jerem twardym $z$ (np. došt $t$ zamiast $d \tau s ̌ t i$ 'córka'; ibid.: 36). I w tym wypadku przyczyna tkwi w redakcji bułgarskiej; w związku z takim właśnie rozwojem w języku bułgarskim (dokładniej w dialektach, które stały się podłożem języka literackiego) już w zabytkach tej redakcji dochodziło do pomieszania obu liter i prawdopodobnie błędy znajdujące się w tekstach redakcji rumuńskiej są spowodowane właśnie tym.

Natomiast miejscowemu podłożu należy przypisywać kolejne typy błędów w zapisie samogłosek. Chodzi przede wszystkim o zapis samogłoski średniej centralnej [e] [ə] ${ }^{6}$. Samogłoska ta jest najbliższa bułgarskiemu [ă] zapisywanemu znakiem przyjętym dla jeru twardego $\mathfrak{r}$, a w tekstach cerkiewnosłowiańskich, przez wzgląd na swoje pochodzenie, również jako samogłoska tylna nosowa $\varrho$. Z punktu widzenia fonetycznego zapis samogłoski rumuńskiej [ă] przez $r$ wydawał się uzasadniony. Zrozumiałe było także użycie do jej oznaczenia $\varrho$, przez analogię do źródeł bułgarskich. Jednak na tym się nie kończyło. W tekstach przebadanych przez cytowaną tu badaczkę spotyka się również oznaczenie tej samogłoski literą ę (z powodu zmieszania $\mathrm{z}$ g) oraz za pomocą jeru miękkiego (z powodu zmieszania z jerem twardym). Inne powody miało natomiast częste oddawanie samogłoski [ə] cyrylicką literą $a$. Szczególnie dużo takich przykładów - przytacza je Djamo-Diaconiță (ibid.: 27) znajduje się wśród rumuńskich nazw własnych pochodzenia słowiańskiego. Przyczyną tego może być albo konserwatywna grafia, albo fakt, że w czasie, gdy imiona te były zapisywane, przejście [a] > [ə] dopiero się dokonywało. Autorka przytacza jako ilustrację nazwę osobową Drăghici, niewątpliwie wywodzącą się z serb. Драzuћ, zapisywaną na trzy różne sposoby: Dragič (pisownia powszechna), Drøgič i Drogič (ibid.: 26). Z kolei przykładem imienia, które prawdopodobnie występowało tylko wśród Słowian, natomiast do przekręcania jego zapisów dochodziło pod wpływem ogólnej niestabilizacji grafii, jest Vladislav, zapisywany także jako Vlodislav i Vlodislav (ibid.: 28).

Dobrym przykładem, świadczącym o zamieszaniu panującym w dystrybucji jerów, jest zapis sbt 'są' zamiast sot(z) (ibid.: 42). Wynika on ze skojarzenia etymologicznego związku samogłoski nosowej [Q] i jeru twardego, a jednocześnie z nieświadomości genetycznej różnicy między prasłowiańskim jerem miękkim a twardym.

6 Nie sposób omawiać system graficzny redakcji rumuńskiej, pomijając całkowicie zapisy wyrazów z samego języka rumuńskiego. Przedstawione tu problemy z zapisem samogłoski [ə] są jednym z dowodów na podobieństwo jej artykulacji w omawianym okresie do artykulacji dzisiejszej. 
Pisarze pochodzenia wołoskiego mieli też problem z używaniem litery zwanej jat', oznaczającej długą samogłoskę szeroką. Samogłoska ta (w systemie IPA w przybliżeniu określana jako [æ]) już w czasie powstawania alfabetów słowiańskich nie była wyraziście określona, na co wskazuje wspólny w alfabecie głagolickim znak dla dwóch szerokich samogłosek oznaczanych w grafii cyrylickiej jako ě i ja, świadczący o bliskości wymowy [æ] oraz [a] po jocie albo po spółgłosce miękkiej (Moszyński 2006: 62). Nałożył się na to zróżnicowany rozwój jat'w różnych językach oraz jego wpływ na inne redakcje języka cerkiewnosłowiańskiego oddziałujące na redakcję rumuńską. W okresie kształtowania się redakcji rumuńskiej istniał już rumuński dyftong ea (w systemie IPA: [e्रa]) i na jego przykładzie widać problemy pisarzy z interpretacją odnośnych liter cyrylickich. Dyftong ten przy użyciu cyrylicy zapisywano przez ě albo ja, ale niekiedy także przez e. Z kolei wyrazy cerkiewnosłowiańskie były czasem błędnie zapisywane z użyciem jat’ zamiast $a$, np. čěša w miejsce čaša 'czasza, naczynie' (Djamo-Diaconiță 1971: 31).

Niekiedy jedynie na podstawie miejsca pochodzenia danego zabytku można określić, który z języków słowiańskich wywarł wpływ na kształt rumuńskiej redakcji cerkiewnosłowiańskiego. Na przykład na terenie Siedmiogrodu i Wołoszczyzny zastępowanie tylnej samogłoski nosowej przez $u$ jest niewątpliwie wpływem serbskim. Na terenie Mołdawii w takiej sytuacji mówi się o oddziaływaniu redakcji ruskiej. Z kolei zastępowanie jat' przez e, często przypisywane wpływowi serbskiemu, może mieć źródło także w zachodnich dialektach bułgarskich.

Mniej problemów powodowały zapisy spółgłosek. Niewątpliwie jest to związane z faktem, że system konsonantyczny języka rumuńskiego dość dobrze odpowiada systemowi słowiańskiemu, dla którego alfabet cyrylicki został stworzony. Tę sytuację można zobrazować, porównując adaptację liter cyrylickich i łacińskich do potrzeb języka rumuńskiego. W alfabecie łacińskim brak było znaków dla spółgłosek zwarto-szczelinowych: przedniojęzykowo-zębowej [c] oraz przedniojęzykowo-dziąsłowej [č]. Być może pod wpływem pisowni włoskiej do zapisu spółgłoski przedniojęzykowo-dziąsłowej [ $\check{c}$ ] została wykorzystana litera $c$, a dla oddania głoski przedniojęzykowo-zębowej [c] wykorzystano $t$ ze znakiem diakrytycznym ț. Podobna sytuacja dotyczy spółgłosek szczelinowych: przedniojęzykowo-zębowej [s] i przedniojęzykowo-dziąsłowej [š], z tym że w tym wypadku dla zębowej spółgłoski [s] wykorzystano łacińskie $s$, natomiast dziąsłowe [š] oddano, stosując znak diakrytyczny ş. W alfabecie cyrylickim dla każdej z tych czterech głosek jest odrębny znak.

Niejednolity charakter redakcji był m.in. powodem sporów na temat jej pochodzenia. Na początku XX w. można było spotkać się z opinią, że jej podłożem była serbska redakcja języka cerkiewnego czy też sam ludowy język serbski. Nie było to spowodowane wyłącznie pewnymi cechami tej redakcji (zresztą spotykanymi dopiero w późniejszych tekstach), ale faktem, że język cerkiewnosłowiański - w odniesieniu do różnych redakcji - bywał określany jako język serbski. Takie określenie mogło być spowodowane nie tylko znaczną rolą średniowiecznego państwa serb- 
skiego, ale także rozpowszechnioną niegdyś opinią o serbskim pochodzeniu języka cerkiewnosłowiańskiego. Jeszcze Josef Dobrovský, który wyraźnie zakwestionował pochodzenie od staro-cerkiewno-słowiańskiego wszystkich pozostałych języków słowiańskich ${ }^{7}$, brał pod uwagę serbską (obok bułgarskiej) podstawę dialektalną języka Cyryla i Metodego (Moszyński 2006: 346).

Dyskusje wzbudzał także charakter języka. Obok przeważających opinii o jego sztucznym, wyłącznie literackim charakterze istniała też hipoteza superstratowego pochodzenia języka słowiańskiego w Rumunii. Jej zwolennikami byli np. slawiści bułgarscy Ljubomir Miletič (1896: 4) i Benju Conev (1934: 281). Taka sytuacja świadczyłaby o zachowaniu na tamtych terenach żywego języka średniobułgarskiego, co byłoby argumentem na rzecz teorii znanej jako tzw. ipoteza transdunăreană, dotyczącej późnego pojawienia się Wołochów na północ od Dunaju. Hipoteza ta nie znajduje dostatecznego uzasadnienia w charakterze rumuńskiej redakcji języka cerkiewnosłowiańskiego, który, aczkolwiek wykazuje wpływy żywego języka, to nie tak silne, jak w wypadku redakcji w krajach słowiańskich, co należy tłumaczyć wyraźną granicą między obcym językiem pisanym a rodzimym mówionym.

Teksty redakcji rumuńskiej nie są w całości opracowane. Poszczególni badacze zajmują się badaniem zjawisk językowych ograniczonych do pewnego terenu. Opracowaniem redakcji z Wołoszczyzny i Siedmiogrodu zajmowała się przede wszystkim L. Djamo-Diaconiță (1971). Badaczem redakcji mołdawskiej jest np. Pandele Olteanu (1961). Choć liczba zabytków piśmiennych powstałych między XIII a XVI w. nie jest mała (Djamo-Diaconiță, zajmując się zaledwie częścią spuścizny redakcji wołoskiej, mianowicie tekstami z kancelarii wołoskich z XIV i XV w., przebadała 467 dokumentów), nie są one opisane tak dobrze, jak pojawiające się dopiero w XVI w. pisma w języku rumuńskim. Nierzadko też cieszyły się większym zainteresowaniem ze strony badaczy słowiańskich, zwłaszcza bułgarskich i rosyjskich, niż rumuńskich. Z drugiej strony - teksty zapisane w języku cerkiewnosłowiańskim są przedmiotem badań rumuńskich historyków, którym dostarczają danych nieznanych z innych źródeł.

Jest jednak również drugi powód, dla którego pisma cerkiewnosłowiańskie zapisane $\mathrm{w}$ omawianej w artykule redakcji budzą zainteresowanie rumuńskich badaczy. Język cerkiewnosłowiański był dla Wołoszczyzny i Mołdawii odpowiednikiem łaciny średniowiecznej w krajach zachodnich. Podobnie jak łacina była językiem religii, administracji, sądownictwa, wreszcie początków literatury w różnych krajach Europy związanych z katolicyzmem, tak te same funkcje pełnił w późniejszej Rumunii język cerkiewnosłowiański. Z tego powodu właśnie w źródłach cerkiewno-

7 Por. „Při zahájení tohoto vědního proudu v slovanské filologii lze připomenout jméno J. Dobrovského, který jednoznačně odlišil staroslověnštinu od praslovanštiny, když odmitl představu, že by staroslověnština była "matkou« slovanských jazyků, a označil ji za jejich "starší sestru"" (Večerka 2010: 91). 
słowiańskich zachowały się wczesne poświadczenia piśmienne języka rumuńskiego, przede wszystkim nazwy własne: terenowe i osobowe, ale również nazwy urzędów, a niekiedy także inne słowa, których pisarz nie chciał czy nie umiał przetłumaczyć na język cerkiewnosłowiański. Warto zauważyć, że nazwami osobowymi były głównie przezwiska, co dostarcza rumuńskim badaczom bogatego materiału leksykalnego reprezentującego najważniejsze części mowy, ponieważ poza przymiotnikami i rzeczownikami w tekstach znajdują się liczne przydomki w formie imiesłowów. Badaniami mającymi na celu wydobycie leksyki rumuńskiej z materiałów cerkiewnosłowiańskich zajął się już w XIX w. wybitny rumuński językoznawca Bogdan Petriceicu Haşdeu (1983), a w drugiej połowie XX w. były one owocnie kontynuowane przez wymienianą tu już wielokrotnie badaczkę tekstów cerkiewnosłowiańskich z Muntenii (Djamo-Diaconiță 1971: 269-377) oraz przez G. Mihăilă, który jest m.in. autorem słownika Dicționar al limbii române vechi (sfîrşitul sec. al X-lea - începutul sec. al XVI-lea) (Mihăilă 1974), zawierającego wybrane wyrazy rumuńskie odnalezione w zabytkach cerkiewnosłowiańskich.

Trzeba podkreślić znaczenie języka cerkiewnosłowiańskiego dla rozwoju całej nowożytnej państwowości rumuńskiej. W przekładach na ten język docierała na ziemie rumuńskie twórczość religijna. Były nań tłumaczone teksty greckie, pierwotnie przede wszystkim religijne, potem także inne. Redagowana była korespondencja między kancelariami poszczególnych możnowładców, spisywane akty nadania i inne dokumenty prawne. Znamy z tego okresu przede wszystkim krótkie teksty nienoszące własnych tytułów, lecz określane w literaturze naukowej według miejsca ich gromadzenia, np. jako rękopisy słowiańskie w bibliotekach Siedmiogrodu i Banatu (Manuscrise slave în bibliotecile din Transilvania şi Banat), rękopisy słowiańskie ze zbiorów Muzeum Historyczno-Archeologicznego Okręgu Maramuresz (Manuscrisele slavone din colecția Muzeului județean de istorie şi arheologie Maramureş). W XVI w. zaczęto tworzyć pierwsze teksty w języku rumuńskim. Wreszcie zaczęly powstawać pierwsze teksty o charakterze literackim. Można do nich zaliczyć annały, mianowicie kronikę początków Państwa Mołdawskiego z XV/XVI w. (Letopisețul de când s-a început Țara Moldovei albo Letopisețul lui Stefan cel Mare $)^{9}$ oraz kroniki autorstwa trzech pisarzy słowiańskich: Makarego, Eutymiusza i Azarego (Cronica lui Macarie, Cronica lui Eftimie i Cronica lui Azarie), a także utwory o charakterze dydaktycznym: nauki Neagoe Basaraba (hospodara wołoskiego) dla syna Teodozjusza

8 Inaczej ten fakt oceniało wielu historyków rumuńskich, por. np. wypowiedź, której autorem jest historyk z przełomu XIX i XX w. Dimitrie Onciul: „Przez Bułgarów i razem z nimi zostaliśmy oddzieleni od Kościoła rzymskiego; od nich przyjęliśmy język cerkiewnosłowiański w Cerkwi i państwie, który zdominuje później całe nasze życie intelektualne aż do XVII wieku. Takie było nasze fatalne historyczne przeznaczenie" (za: Klimkowski 2009: 49-50).

9 Oryginalne cerkiewnosłowiańskie teksty tych annałów zostały opublikowane w jednym woluminie wraz z innymi kronikami (Bogdan 1891: 140-189). 
(Învățăturile lui Neagoe Basarab către fiul sau Theodosie) ${ }^{10}$. W tym czasie powstała też opowieść w dziewiętnastu częściach o dokonaniach Włada Palownika zwanego Drakulą - Povestire despre voievodul Dracula ${ }^{11}$. Wszystkie wymienione wyżej dzieła są dziś znane głównie w przekładach na język rumuński. Slavona românească trwała jeszcze przez dwa wieki, stopniowo ustępując rumuńskiemu.

Widocznym śladem oddziaływania języka cerkiewnosłowiańskiego na rumuński był jeszcze przez długie lata alfabet. Do połowy XIX w. oficjalnym alfabetem języka rumuńskiego była cyrylica. Oficjalną datą zmiany alfabetu na łaciński jest rok 1862, jednak trzeba mieć świadomość, że XIX w., począwszy od roku 1830, to okres przejściowy. Już w latach 1830-1860 można było zaobserwować istnienie tzw. alfabetu przejściowego (mieszanego), tj. cyrylicy ewoluującej w kierunku grafii łacińskiej. Dla drugiej połowy XIX w. charakterystyczne były problemy z adaptacją alfabetu łacińskiego (wybór między pisownią etymologiczną a fonetyczną, między oddawaniem głosek nieznanych alfabetowi łacińskiemu dwuznakami bądź przy użyciu diakrytów). Jeszcze wcześniej, bo już od końca XVIII w., podejmowano działania, które miały na celu przywrócenie językowi rumuńskiemu romańskiego charakteru, co polegało na zastępowaniu (np. w utworach literackich) wyrazów pochodzenia słowiańskiego neologizmami wzorowanymi najpierw na leksyce łacińskiej, a od pierwszej połowy XIX w. głównie na francuskiej oraz - w mniejszym stopniu - włoskiej ${ }^{12}$. Proces ten, w znacznym stopniu udany, doprowadził do przesunięcia wielkiej liczby zapożyczeń słowiańskich do pozycji dialektyzmów i archaizmów.

Artykuł niniejszy ma charakter zarysu problematyki związanej z rumuńską redakcją języka cerkiewnosłowiańskiego. Dlatego też zostały w nim skrótowo przedstawione najważniejsze fakty, mało znane w krajach słowiańskich, w tym - w Polsce i wśród polskich slawistów. Kontynuacją tego tematu może być zaprezentowanie najstarszej leksyki rumuńskiej zachowanej w zabytkach cerkiewnosłowiańskich, która, jak dotąd, jest dostępna głównie w opracowaniach napisanych w języku rumuńskim.

10 Fragmenty tekstu w języku cerkiewnosłowiańskim zostały odnalezione przez Piotra A. Lavrova w Bibliotece Narodowej w Sofii i opublikowane w Sankt Petersburgu (Lavrov 1904). O sporze dotyczącym autentyczności tych fragmentów zob. Ciobanu 1992: 83-84. Faksymile oryginału wraz z nowym tłumaczeniem na język rumuński opublikował G. Mihăilă (1996).

11 Tytuł oryginału cerkiewnosłowiańskiego: Skazanie o Drakulě Vojevodě. Warto zauważyć, że Wład Palownik przedstawiony jest w tym tekście jako postać pozytywna (Olteanu 1961: 17).

12 Dziękuję Recenzentowi artykułu za uściślenie informacji dotyczących reromanizacji języka rumuńskiego. 


\section{Literatura}

Bogdan I., 1891, Vechile cronice moldovenesci pana la Urechia. Texte slave cu studiu, traduceri si note, Bucuresci.

Ciobanu S., 1992, Istoria literaturii române vechi, Bucureşti.

Conev B., 1934, Istoriâ na b"lgarski ezik, t. II: Ezikovi vzaimnosti meždu b"lgari i rum"ni, (posm"rtno izdanie pod red. na prof. St. Mladenov), „Nauka i Izkustvo”, Sofiâ.

Djamo-Diaconiță L., 1971, Limba documentelor slavo-române emise în Țara Românească in sec. XIV şi XV, Bucureşti.

НАмм J., 1958, Staroslovenska gramatika, Zagreb.

HaşDeu B.P., 1983, Cuvente den bătrîni, t. 1: Limba Română vorbită între 1550-160o. Studiu paleografico-linguistic de B. Petriceicu Hasdeu cu observațiuni filologice de Hugo Schuhardt, ed. ingrijită, studiu introductiv şi note de G. Mihăilă, Bucureşti.

Ivanov I. (red.), 1914, Istorïâ slavěnobolgarskaâ, sobrana i nareždena Paisiem" Ieromonahom" $v^{\prime \prime}$ lèto 1762 , Sofiâ.

KLimkowski T., 2009, Początki piśmiennictwa w języku rumuńskim a ideologia reformacyjna, „Balcanica Posnaniensia” XVI, s. 47-57.

Klimkowski T., 2011, Chrystianizacja ludności romańskiej na Bałkanach $w$ świetle faktów historycznych i językowych, „Balcanica Posnaniensia” XVIII, s. 43-54.

LAvrov P., 1904, Slova nakazatel'nye voevoda valašskogo Ioanna Nâgoâ $k$ synu Feodosiû, Sankt-Peterburg.

MıнӑILĂ G., 1972, Contribuții la istoria culturii şi literaturii române vechi, Bucureşti.

MıнĂILĂ G., 1973, Ǔžnoslavânskij - literaturnyj âzyk v rumynskih knâžestvah i ego harakternye leksičeskie čerty. Doklady i soobŝeniâ predstavlennye na VII Meždurodnom S"ezde Slavistov (Varšava, 21-27 avgusta 1973 g.), Bucureşti.

MıнӑILĂ G., 1974, Dicționar al limbii române vechi (sfîrşitul sec. al X-lea - începutul sec. al XVI-lea), Bucureşti.

MinĂılă G. (red.), 1996, Neagoe Basarab, Învățăturile lui Neagoe Basarab către fiul său Theodosie. versiunea originală, facsimil și ediție bilingvă slavonă-română, București.

Miletič L., 1896, Dako-rom"nite i tâhnata slavânska pismenost. cz. II: Novi vlaho-b"lgarski gramoti ot Brašov, „Sbornik" za Narodni Umotvoreniâ. Nauka i Knižnina” XIII, s. 3-152.

Mladenov S., 1979, Istoriâ na b"lgarski ezik, Sofiâ.

Moszyński L., 2006, Wstęp do filologii słowiańskiej, wyd. II zm., Warszawa.

Olteanu P., 1961, Limba povestilor slave despre Vlad Tepeş, Bucureşti.

VeČERKa R., 2010, Staroslověnská etapa českého písemnictví, Praha. 


\section{The Romanian Redaction of the Church Slavonic Language - an Outline of the Problem Summary}

The article is devoted to the Romanian redaction of the Church Slavonic language. More recent redactions of the Old Church Slavonic language emerged in all areas inhabited by Slavs of the Orthodox faith. Apart from the national redactions of the Church Slavonic language, which developed in Slavic countries, a form of this language with its own peculiar peculiarities also emerged in the territory of present-day Romania. Between the $13^{\text {th }}$ and the $16^{\text {th }}$ century, the official language of Moldavia and Wallachia (the lands which subsequently became part of Romania) was a Slavic language in a form based on a Bulgarian version of the Church Slavonic language. It gradually developed distinct features, so that we may already speak about a Romanian redaction of the Church Slavonic language in the $15^{\text {th }}$ and $16^{\text {th }}$ centuries. 